\title{
Chemical composition and antibacterial activity of oils from Chrysicthys nigrodigitatus and Hepsetus odoe, two freshwater fishes from Yabassi, Cameroon
}

Mouokeu Raymond Simplice ${ }^{1 *}$, Womeni Hilaire Macaire ${ }^{2}$, Njike Ngamga Fabrice Hervé ${ }^{2}$, Tonfack Djikeng Fabrice ${ }^{2}$, Djopnang DJimbie Justin ${ }^{1}$, Tchoumbougnang François ${ }^{1}$ and Kuiate Jules-Roger ${ }^{3}$

\begin{abstract}
Backgrounds: Oils of fish origin are a very rich source of Omega -3 and Omega -6 fatty acids. They have been suggested to provide numerous health benefits for humans involving antimicrobial properties. Chrysichthys nigrodigitatus and Hepsetus odoe are two fishes well known in Cameroon. The chemical composition and the antibacterial activity of these fishes derived oils are unknown. The study was designed to valorise C. nigrodigitatus and H.s odoe oils activity against food poisoning bacteria.

Methods: Oils were extracted by pressing and maceration methods. Their quality was assessed by analysing quality indexes including peroxides, acid, iodine, anisidine and thiobarbituric acid values. Chemical analysis was established by gas chromatography coupled to flame ionization detector. Antibacterial activity was evaluated by broth microdilution method.

Results: $C$. nigrodigitatus oil obtained by maceration exhibited highest acid $(7.33 \pm 0.00 \mathrm{mg} \mathrm{KOH} / \mathrm{g}$ ), anisidine (34.5 \pm 1.84$)$ and thiobarbituric acid $(7.50 \pm 0.30 \mu \mathrm{mol} \mathrm{MDA} / \mathrm{Kg})$ values compared to that obtained by pressing method $(9.13 \pm 0.64$ and $6.72 \pm 0.34 \mu \mathrm{mol} \mathrm{MDA} / \mathrm{Kg}$ ) respectively. H. odoe oil obtained by pressing method showed highest peroxide value $\left(6.22 \pm 1.31 \mathrm{meq} \mathrm{O}_{2} / \mathrm{kg}\right)$. Oil chemical analysis revealed long chain polyunsaturated fatty acids of the $\omega-3$ family: linolenic acid (C18:3); eicosapentaenoic acid (C20:5) and docosahexaenoic acid (C22:6) and $\omega$-6 family; arachidonic acid (C20:4). In addition, C. nigrodigitatus oil obtained by pressing and maceration methods showed Minimum Inhibitory Concentrations (MIC) values ranging from 32 to $64 \mathrm{mg} / \mathrm{ml}$. H. odoe oil obtained by pressing method revealed MIC values ranging between 8 and $64 \mathrm{mg} / \mathrm{ml}$.
\end{abstract}

Conclusions: $C$. nigrodigitatus and $H$. odoe oils have activity against food poisoning bacteria, due to their chemical composition.

Keywords: Chrysichthys nigrodigitatus, Hepsetus odoe, Fish oil composition, Antibacterial activity

\footnotetext{
* Correspondence: moraysi@yahoo.fr

'Laboratory of Fisheries Resources, Institute of Fisheries and Aquatic

Sciences, University of Douala, Po Box 7236, Douala, Cameroon

Full list of author information is available at the end of the article
} 


\section{Background}

Food is a source of hazards which can be either biological or chemical. Biological hazards are most frequent due to the regular ingestion of microorganisms and toxins, causing food intoxication in one out of three persons nowadays [1]. Food intoxications have a large social impact and have caused many diseases including typhoid fever, paratyphoid fever, brucellosis, botulism, cholera [2]. To limit the incidence of these diseases, antibacterial extracts including plants have been used [3]. These substances sometimes produce harmful effects. Fatty acids are natural constituents of foods with no side effect on human health. They are the main constituents of edible oils and confer to their stability countless nutritional and biological properties. Fish oils are good sources of polyunsaturated fatty acids [4]. The $\omega-3$ and $\omega-6$ fatty acids of fish oils are known for their therapeutic properties [5, 6]. Previous studies highlighted the antibacterial activity of polyunsaturated fatty acids from several fish oil species [5, 7]. They could be an alternative of dietary supplement against bacteria responsible for food poisoning diseases.

Cameroon is located in one of the largest river basins in the world. Its aquatic fauna is abundant and diversified. However, there are few data on fish oil composition [8] and their antimicrobial activities had almost not yet been initiated. Chrysichthys nigrodigitatus and Hepsetus odoe are widespread in the tropical regions. $C$. nigrodigitatus belongs to Claroteidae family. It is highly commercial, marketed fresh, smoked or dried, and apart from being a cheap source of highly nutritive protein, it also contains other essential nutrients required by the body [9]. $H$. odoe is usually found near the banks of rivers in heavy vegetation, but can also be found in swampy environments, lagoons and backwaters. It bears a striking resemblance to the European pike. It is however, the only member of its genus [10].

The present study was designed to promote fish oils as a complement against bacteria responsible for food poisoning diseases.

\section{Methods}

\section{Fish samples}

Samples of $C$. nigrodigitatus and $H$. odoe were collected in Yabassi, Cameroon. They were stored in ice and transported to the laboratory. Identification was made by ichtyologists of the Laboratory of Fisheries Resources at the Institute of Fisheries and Aquatic Sciences. The average lengths of these two fishes were $41.96 \pm 9.78 \mathrm{~cm}$ and $31.00 \pm 0.50 \mathrm{~cm}$ respectively for $C$. nigrodigitatus and $H$. odoe. Their average weights were $446.06 \pm 67.67 \mathrm{~g}(C$. nigrodigitatus) and $53.57 \pm 3.10 \mathrm{~g}$ (H. odoe) .

\section{Microorganisms}

Microorganisms used included Gram+ and Gram- bacteria. Gram+ bacteria involved one strain of Staphylococcus aureus (ATCC 1026), four clinical isolates of Staphylococcus aureus and one clinical isolate of Enterococcus feacalis. Gram- bacteria included Klebsiella pneumoniae, Salmonella paratyphi A and Salmonella paratyphi $\mathrm{S}$ isolates.

\section{Oil extractions}

Two techniques were used for oil extraction. The cooking-pressing method used for both fish species and maceration used for $C$. nigrodigitatus.

\section{Cooking-pressing method}

Twelve kilograms of each fish were washed and the undesirable parts including heads, intestines and gills were discarded. Fleshes were cooked between 80 and $85{ }^{\circ} \mathrm{C}$ in a household autoclave containing water on Kinderbo gas type plate for $20 \mathrm{~min}$. The obtained fish was pressed to separate the liquid from the solid phase. The resulting pressed juice was decanted for $45 \mathrm{~min}$ and centrifuged $15 \mathrm{~min}$ at $5400 \mathrm{rpm} / \mathrm{min}$ [11]. The obtained oils were dried, weighed and stored at $4{ }^{\circ} \mathrm{C}$ until use.

\section{Maceration}

C. nigrodigitatus fleshes were dried $24 \mathrm{~h}$ in an oven at $45{ }^{\circ} \mathrm{C}$. Samples were further ground to yield a fine powder. $100 \mathrm{~g}$ powder was mixed with $500 \mathrm{ml}$ hexane, macerated and stirred three times within $24 \mathrm{~h}$. Upon maceration, the homogenate was filtered and concentrated under vacuum using rotary vapour $\left(40{ }^{\circ} \mathrm{C}\right)$. The resulting extract was placed in an oven at $35{ }^{\circ} \mathrm{C}$ for 2 days to remove residual solvent, weighed and stored at $4{ }^{\circ} \mathrm{C}$ until used [12].

\section{Determination of oil quality indexes}

The peroxide value was evaluated using standard spectrophotometric method [13]. Determination of thiobarbituric acid value was done following the method recommended by American Oil Chemists' Society [14]. The iodine value was assessed as recommended by AFNOR [15]. The acid value was determined according to standard NFT60-204 of the French Association for Standardization [15]. The anisidine value was evaluated according to AOCS Official Method Cd 18-90 "p-anisidine value" [14].

\section{Fatty acid profile}

The fatty acid profile of oil samples were determined by gas chromatography coupled to a flame ionization detector (GC-FID). Briefly, the fatty acid methyl esters were prepared by transesterification, using $2 \%$ sulfuric acid in methanol [16]. Analysis were performed on a gas chromatograph (Agilent Technologies, Palo Alto, CA, USA), serial number $7890 \mathrm{~A}$, coupled to a flame ionization detector, using a capillary column DB-225 $(30 \mathrm{~m} \times 0.25 \mathrm{~mm}$, film thickness $0.25 \mu \mathrm{m})$. The initial column temperature was $160{ }^{\circ} \mathrm{C}$ for $2 \mathrm{~min}$, then increased to $220^{\circ} \mathrm{C}\left(5^{\circ} \mathrm{C} / \mathrm{min}\right)$ 
and maintained for $10 \mathrm{~min}$. Nitrogen was used as mobile phase with flow rate $1.5 \mathrm{ml} / \mathrm{min}$. The temperature of the injector and detector were maintained at $230{ }^{\circ} \mathrm{C}$ and $250{ }^{\circ} \mathrm{C}$ respectively for $20 \mathrm{~min}$. The identification of fatty acid was based on the comparison of retention time with that of standard reference fatty acid methyl esters performed under same conditions.

\section{Antibacterial activity}

The oil's antibacterial activity was evaluated by broth microdilution method in a 96-wells microtitre plates [17]. Bacterial suspensions of about $1.5 \times 10^{8} \mathrm{CFU} / \mathrm{ml}$ (Mc Farland turbidity standard no. 0.5) was prepared from an overnight culture. The inoculum was obtained following 100 times dilution $\left(1.5 \times 10^{6} \mathrm{CFU} / \mathrm{ml}\right)$. The oil stock solution was prepared in $5 \%$ tween 20 . A series of two fold dilutions were performed to obtain final concentration range of 0.5 to $64 \mathrm{mg} / \mathrm{ml}$ in a total volume of $100 \mu \mathrm{l} /$ well. Each well was further diluted with $100 \mathrm{ml}$ inoculum. Plates were further incubated at $35{ }^{\circ} \mathrm{C}$ for $18 \mathrm{~h}$. Growth was monitored using $P$ - iodotetrazolium chloride (INT; $0.2 \mathrm{mg} / \mathrm{ml}$ )) [18]. Viable bacteria change the yellow dye of iodonitrotetrazolium to a pink colour. The lowest concentration of oil, at which no visible colour change was noted was considered as MIC. Ciprofloxacin was used as positive control at concentrations ranging from 0.0625 to $128 \mu \mathrm{g} / \mathrm{ml}$.

\section{Statistical analysis}

The values of the oil's quality index were expressed as mean \pm standard deviation. For a given index value, the One-Way ANOVA was used to detect differences between oil quality indexes values. When significant, the Waller Duncan test $(p<0.05)$ was used for comparison.

\section{Results}

\section{Fish oil extraction yields}

C. nigrodigitatus oil was obtained with average yields of $6.52 \%$ and $5.8 \%$ respectively by the cooking-pressing and maceration methods. $H$. odoe oil was obtained with a yield of $4.31 \%$ by cooking pressing- method.

\section{Fish oil chemical characteristics \\ Quality index}

The quality index of oils extracted from C. nigrodigitatus and $H$. odoe are summarized in Table 1 . The acid value of the oil extracted from $H$. odoe by cooking-pressing method was higher than $C$. nigrodigitatus oil obtained by the same method. Oils extracted from $C$. nigrodigitatus and $H$. odoe by cooking-pressing method had higher iodine values compared to $C$. nigrodigitatus oil extracted by maceration. $H$. odoe's oil, obtained by cooking-pressing method presented the highest peroxide value. C. nigrodigitatus oil, extracted by maceration increases by approximately four times the anisidine value compared to that obtained by cooking-pressing method. The anisidine value of the oil extracted from $H$. odoe by cooking-pressing method was lower than that of $C$. nigrodigitatus obtained by the same method.

\section{Fish oil chemical composition}

The fatty acid profile of $C$. nigrodigitatus and $H$. odoe oils are presented in Table 2. Twenty fatty acids (C14 C22) were identified in C. nigrodigitatus and H. odoe oils extracted by cooking-pressing method and seventeen fatty acids in C. nigrodigitatus oil extracted by maceration. These include saturated, monounsaturated and polyunsaturated fatty acids.

Palmitic acid was the most abundant saturated fatty acid in these three oils. C. nigrodigitatus oil extracted by maceration has the highest palmitic acid content (34.07\%) compared to that obtained from C. nigrodigitatus by cooking-pressing method (27.55\%) and $H$. odoe oil (24.25\%).

Among the monounsaturated fatty acids, oleic acid was the most represented in the three samples. $H$. odoe oil had a higher level of oleic acid (27.28\%). Cetoleic acid (C22:1) was not found in C. nigrodigitatus oil extracted by maceration method.

The three oils contain long chain polyunsaturated fatty acids of the $\omega-3$ family (linolenic acid (C18:3); eicosapentaenoic acid (C20:5) and docosahexaenoic acid (C22:6)) and the $\omega-6$ family (arachidonic acid (C20:4), linoleic acid (C18:2). Eicosapentaenoic and docosahexaenoic acids were most represented. The eicosapentaenoic and docosahexaenoic acids content in $C$. nigrodigitatus oil obtained by cooking-pressing method decreased by more than half to that obtained from the same fish by maceration. Oils extracted from $C$. nigrodigitatus had higher proportion of these two fatty acids compared to that derived from $H$. odoe. Lignoceric acid was absent in C. nigrodigitatus oil extracted by maceration. Arachidonic acid (C20:4) was absent in C. nigrodigitatus oil extracted by maceration. In general, oil extracted from $C$. nigrodigitatus by cooking-pressing method contained high levels of $\omega-3$ fatty acids compared to that obtained from $C$. nigrodigitatus by maceration. The oil extracted from $H$. odoe contained high of $\omega-3$ fatty acids. Similar observations were made with $\omega-6$ fatty acids. The sum of $\omega-3$ fatty acids contained in these three oils was greater than those of $\omega-6$ fatty acids.

\section{Fish oil antibacterial activity}

Oils extracted from $C$. nigrodigitatus and $H$. odoe showed antibacterial activities on tested bacteria (Table 3). C. nigrodigitatus oils obtained by both cooking-pressing and maceration methods showed MICs values ranging between 32 and $64 \mathrm{mg} / \mathrm{ml}$ while $H$. odoe oil obtained by 
Table 1 Oil indexes of C. nigrodigitatus and H. odoe obtained by cooking-pressing method and maceration in hexane

\begin{tabular}{|c|c|c|c|c|c|}
\hline Samples & $\begin{array}{l}\text { Peroxyde value } \\
\left(\mathrm{meq} \mathrm{d}^{\prime} \mathrm{O}_{2} / \mathrm{Kg}\right)\end{array}$ & Anisidine value & $\begin{array}{l}\text { Thiobarbituric value } \\
(\mu \mathrm{mol} \mathrm{MDA} / \mathrm{Kg})\end{array}$ & $\begin{array}{l}\text { lodine value } \\
\left(\mathrm{gl}_{2} / 100 \mathrm{~g}\right)\end{array}$ & $\begin{array}{l}\text { Acid value } \\
(\mathrm{mg} \mathrm{KOH} / \mathrm{g})\end{array}$ \\
\hline H. odoe by cooking-pressing method & $6.22 \pm 1.31^{a}$ & $5.05 \pm 0.15^{c}$ & $6.59 \pm 0.07^{b}$ & $94.85 \pm 0,31^{b}$ & $0.98 \pm 0.14^{b}$ \\
\hline C. nigrodigitatus by cooking-pressing method & $4.49 \pm 1.65^{\mathrm{b}}$ & $9.13 \pm 0.64^{b}$ & $6.72 \pm 0,34^{b}$ & $96.28 \pm 0,15^{\mathrm{a}}$ & $0.70 \pm 0.14^{c}$ \\
\hline C. nigrodigitatus by maceration method & $4.49 \pm 0,40^{b}$ & $35.43 \pm 1.84^{\mathrm{a}}$ & $7.50 \pm 0.30^{\mathrm{a}}$ & $82.64 \pm 1,11^{c}$ & $7.33 \pm 0.00^{\mathrm{a}}$ \\
\hline
\end{tabular}

Values are shown as mean \pm standard deviation of triplicates; $n=3$. For a given oil index, values followed by different letters as superscript are significantly different, Waller Ducan test $(p<0.05)$

cooking- pressing method showed MICs values between 8 and $64 \mathrm{mg} / \mathrm{ml}$. C. nigrodigitatus oil extracted by cookingpressing method was active on six of the eight tested bacteria, whereas that obtained by maceration was active on four of the eight tested bacteria. H. odoe oil extracted by cooking-pressing method was active on seven of the eight tested bacteria. The most important activity was obtained with this oil on two of the three strains of $S$. aureus with
MIC value of $8 \mathrm{mg} / \mathrm{ml}$. Considering the whole antibacterial activity, it appears that $H$. odoe oil obtained by cooking-pressing method was the most active on the tested bacteria.

\section{Discussion}

The extraction yields of $C$. nigrodigitatus oils were $6.52 \%$ and $5.8 \%$ respectively, for the cooking-pressing methods

Table 2 Fatty acids profiles of C. nigrodigitatus and H. odoe oils obtained by cooking-pressing method and maceration in hexane

\begin{tabular}{|c|c|c|c|c|}
\hline Acides gras & Common name of fatty acid & $\begin{array}{l}\text { C. nigrodigitatus oil by } \\
\text { cooking-pressing method }\end{array}$ & $\begin{array}{l}\text { C. nigrodigitatus oil by } \\
\text { maceration }\end{array}$ & $\begin{array}{l}\text { H. odoe oil by cooking } \\
\text { pressing method }\end{array}$ \\
\hline C14:0 & Myristic acid & 4.58 & 2.86 & 1.25 \\
\hline C15:0 & Pentadecanoic acid & 1.05 & 0.89 & 0.74 \\
\hline C16:0 & Palmitic acid & 27.55 & 34.07 & 24.25 \\
\hline C17:0 & Heptadecanoic acid & 1.58 & 1.34 & 1.70 \\
\hline C18:0 & Stearic acid & 13.06 & 12.01 & 8.32 \\
\hline C20:0 & Arachidic acid & 1.73 & 0.34 & 0.76 \\
\hline C22:0 & Behenic acid & 0.38 & 0.21 & 0.42 \\
\hline C24:0 & Lignoceric acid & 0.16 & / & 0.15 \\
\hline$\Sigma$ SFA & & 50.09 & 51.72 & 37.59 \\
\hline $\mathrm{C} 16: 1$ & Palmitoleic acid & 4.05 & 4.28 & 11.67 \\
\hline C17 :1 & Heptadecanoic acid & 1.07 & 0.76 & 0.69 \\
\hline $\mathrm{C} 18: 1$ & Oleic acid & 23.98 & 26.30 & 27.28 \\
\hline$C 20: 1$ & cis-11 Eicosenoic acid & 1.13 & 2.57 & 0.24 \\
\hline $\mathrm{C} 22: 1$ & Erucic acid & 0.36 & / & 0.08 \\
\hline ¿MUFA & & 30.59 & 33.91 & 39.96 \\
\hline $\mathrm{C} 18: 2$ & Linolelaidic acid & 3.28 & 3.53 & 7.19 \\
\hline $\mathrm{C} 18: 3$ & linolenic acid & 1.65 & 1.37 & 3.93 \\
\hline$C 20: 2$ & Docosadienoic acid & 0.40 & 0.78 & 1.06 \\
\hline$C 20: 3$ & Eicosatrienoic acid & 0.57 & 3.01 & 3.84 \\
\hline$C 20: 4$ & Arachidonic acid & 2.04 & / & 0.32 \\
\hline$C 20: 5$ & Eicosapentaenoic acid & 4.10 & 1.29 & 1.45 \\
\hline$C 22: 6$ & Docosahexaenoic acid & 6.36 & 2.96 & 2.45 \\
\hline$\Sigma P U F A$ & & 18.4 & 12.94 & 20.24 \\
\hline$\Sigma U F A$ & & 48.99 & 46.85 & 60.2 \\
\hline$\Sigma n-3$ & & 12.11 & 5.62 & 7.83 \\
\hline$\Sigma n-6$ & & 5.32 & 3.53 & 7.51 \\
\hline$\sum n-3 / \Sigma n-6$ & & 2.27 & 1.59 & 1.04 \\
\hline
\end{tabular}

Values are expressed as percentage of fatty acid. PUFA polyunsaturated fatty acid, UFA unsaturated fatty acid, MUFA monounsaturated fatty acid, SFA saturated fatty acid 
Table 3 Minimum Inhibitory Concentrations ( $\mathrm{mg} / \mathrm{ml}$ ) of C. nigrodigitatus and $\mathrm{H}$. odoe oils as a function of bacteria and extraction methods

\begin{tabular}{|c|c|c|c|c|}
\hline & $\begin{array}{l}\text { C. nigrodigitatus oil } \\
\text { (cooking-ressing method) }\end{array}$ & $\begin{array}{l}\text { C. nigrodigitatus } \\
\text { oil (maceration) }\end{array}$ & $\begin{array}{l}\text { H. odoe oil (cooking } \\
\text { pressing method) }\end{array}$ & $\begin{array}{l}\text { Ciprofloxacin } \\
(\mu \mathrm{g} / \mathrm{ml})\end{array}$ \\
\hline \multicolumn{5}{|l|}{ Gram+ bacteria } \\
\hline S.aureus ATCC1026 & 64 & ud & 64 & 0.125 \\
\hline S. aureus 22JN & ud & ud & 8 & 0.125 \\
\hline S. aureus 55M & ud & ud & 8 & 0.125 \\
\hline S. aureus 18J & 64 & 64 & 64 & 0.125 \\
\hline E. feacalis & 64 & 64 & ud & 0.125 \\
\hline \multicolumn{5}{|l|}{ Gram- bacteria } \\
\hline S. parathyphis & 32 & 32 & 64 & 0.125 \\
\hline S. parathyphi A & 64 & ud & 64 & 0.125 \\
\hline K. pneumonia & 64 & 64 & 64 & 0.125 \\
\hline
\end{tabular}

Ud undetermined

and maceration. The extraction yield of $H$. odoe was 4.31\% by cooking-pressing method. According to Linder et al. [19], fishes with oil content less than $5 \%$ are lean fishes, those containing 5 to $10 \%$ are semi fatty fishes and beyond $10 \%$ are considered fat. Therefore, C. nigrodigitatus with a yield of $5.8 \%-6.52 \%$ is a semi fatty fish unlike $H$. odoe which is a lean fish (yield of 4.31\%).

The acid value is a measure of the amount of free acids present in a given amount of fat. C. nigrodigitatus oil extracted by maceration method had the highest amount of free acids compared to that of the cookingpressing method. This increase might be related to the extraction process. However, the acid values of $C$. nigrodigitatus and $H$. odoe oils extracted by cooking-pressing method remain in the standard (less than $3 \mathrm{mg} \mathrm{KOH} / \mathrm{g}$ of oil) $[18,20]$. This was not the case with $C$. nigrodigitatus oil extracted by maceration. The oil's iodine value reflects its susceptibility to oxidation. A decrease is generally attributed to the destruction of double bonds, polymerization or split [21].

C. nigrodigitatus and $H$. odoe oils, extracted by cooking-pressing method had higher iodine values compared to $C$. nigrodigitatus oil extracted by maceration. This could be due to the fact that unsatured bonds present in $C$. nigrodigitatus and $H$. odoe oils obtained by cookingpressing method were not affected during extraction. Therefore, the cooking-pressing method could be the best method of oil extraction of these two fishes.

Peroxide value measure the amount of hydroperoxide; the primary product of oxidized fats [22]. H. odoe oil extracted by cooking-pressing method showed the highest peroxide value while that extracted from $C$. nigrodigitatus showed the lowest. The high content of hydroperoxides in $H$. odoe sample compared to those extracted from $C$. nigrodigitatus revealed its deterioration caused by the alteration of unsaturated fatty acids into hydroperoxides [23].
The anisidine value reflects the secondary oxidation products, specifically 2-alkenals and 2.4-dienals unlike thiobarbituric acid value which allows highlighting the malondialdehydes which characterise the last steps of fatty acid oxidation. C. nigrodigitatus oil extracted by maceration presented an oxidation rate which is approximately four times higher than that of oils extracted by the cooking pressing method. Moreover, the oil extracted from $C$. nigrodigitatus by maceration exhibited the highest thiobarbituric acid value compared to the oils extracted by cooking-pressing method, reflecting last step of this oil's oxidation. However, thiobarbituric acid values obtained with oils extracted from the two fishes regardless of the method fell within the standard range since values were below $10 \mu \mathrm{mol} \mathrm{MDA} / \mathrm{Kg}$ fish [20].

From the various oil indexes, it appears that $C$. nigrodigitatus oil extracted by maceration was the most affected. Oils from $C$. nigrodigitatus and $H$. odoe obtained by cooking-pressing method showed quality indexes within the standards, meaning that they were of good quality. Nevertheless, alternative extraction methods need to be carried out in order to preserve these oils.

Oil from C. nigrodigitatus extracted by cooking-pressing method exhibited the lowest rate of monounsaturated fatty acids, this reflects its low rate of oleic acid (C18:1). Oil from $C$. nigrodigitatus obtained by cooking-pressing method revealed high proportions of polyunsaturated fatty acids compared to maceration. Instead, low rate of polyunsaturated fatty acid in $C$. nigrodigitatus oil obtained by maceration was observed and could be due to the absence of lignoceric, cetoleic arachidonic acid and low rates of eicosapentaenoic and docosahexaenoic acids. These fatty acids could have been oxidized and converted into hydroperoxides and malondialdehydes. This is in line with the previous result showing that the oil from $C$. nigrodigitatus obtained by maceration was more affected during the extraction process. 
Oils extracted from C. nigrodigitatus and $H$. odoe revealed high rates of $\omega-3, \omega-6$ and monounsaturated fatty acids. The high $\omega-3 / \omega-6$ constitutes their peculiarity unlike those from Sardinella longiceps and Sardinella fimbriata which are two fatty fishes from India [5].

The major compounds identified in $C$. nigrodigitatus and $H$. odoe oils were saturated fatty acids with palmitic acid being the most represented. They were followed by monounsaturated fatty acids predominantly oleic acid and followed by polyunsaturated fatty acids mostly linolelaidic acid. This repartition is quite different to that reported with the chemical composition of Sardinella longiceps and Sardinella fimbriata. Indeed, results revealed with both fishes oil composition showed that the major compounds identified were unsaturated fatty acids with a predominance of C20:5 (EPA) and C 22:6 (DHA) [5]. They are also different from Eusphyra blochii and Carcharhinus bleekeri marine fish oil where dienoic and trienoic fatty acids were found in trace amount. The findings are nevertheless similar to those reported with these marine fishes, where palmitic acid was one of the major saturated fatty acid found, oleic and palmitoleic fatty acids were the major constituents of monounsaturated fatty acids [24].

Cod liver oil is the most marketed fish derived oil for its nutritional value. EPA and DHA, its main constituent are beneficial to health. According to previous studies, they among others, ameliorate visual and cerebral functions. They are also used for regulation of some metabolic and physiological dysfunctions and have positive effects on skin, hair, nails and teeth. The oils studied also contain EPA and DHA fatty acids in significant proportions, therefore could have similar properties.

Polyunsaturated (PUFA) and monounsaturated (MUFA) fatty acids have been known to provide varied health benefits such as minimizing inflammation and/or acting as antioxidants. Recent studies highlighted n-3 PUFA and their ester derivatives antibacterial activity against various oral pathogens, including S. mutans, C. albicans, A. actinomycetemcomitans, $F$. nucleatum, and $P$. gingivalis. The major n-6 PUFAs, (linoleic acid, $\gamma$-linolenic acid, arachidonic acid), the n-7 MUFA, palmitoleic acid, the n-9 MUFA and oleic acid (OA) were found to be responsible for this activity [25].

Oils from $C$. nigrodigitatus and $H$. odoe revealed MIC values ranging between 8 and $64 \mathrm{mg} / \mathrm{ml}$, reflecting their activities against bacteria responsible for food poisoning.

Oil composition of this two fish species were found to contain significant amounts of PUFA including linolenic acid, arachidonic acid, palmitoleic acid and oleic acid which could explain their antimicrobial activity. Similar results were earlier reported [25-28].

Oil from $H$. odoe obtained by cooking-pressing method showed activity on seven of the eight tested bacteria compared to those from $C$. nigrodigitatus obtained by cooking -pressing and maceration methods which revealed activity on six and four tested bacteria respectively. On the other hand, the best activity of $C$. nigrodigitatus oil obtained by cooking-pressing method compared to that obtained by maceration was noticed. Differences in antibacterial activity of $C$. nigrodigitatus oils could be attributed to oxidation of PUFA responsible for the activity through the maceration method. Moreover, the proportion of the PUFA responsible for the activity in the mixture may also be associated with the activity, explaining the differences between $C$. nigrodigitatus and $H$. odoe oils obtained with same procedure.

Bacteria including S. parathyphi A, K. pneumoniae and $S$. aureus are responsible for food intoxications. In addition to suffering and death, these bacteria cause considerable economic losses [29]. S. aureus and S. parathyphi A are two microorganisms responsible for food intoxication and typhoid fever respectively [30]. They were sensitive to $C$. nigrodigitatus and $H$. odoe oils, thereby indicating that these oils are potent antibacterial agents which could serve either as dietary supplements to fight against food infections caused by these bacteria or cooked in these forms to combine nutritive and curative properties of the fishes.

\section{Conclusion}

Oils from C. nigrodigitatus and $H$. odoe showed significant antibacterial properties which can be justified by the presence of different classes of fatty acids including PUFA including, linolenic acid, arachidonic acid, palmitoleic acid and oleic acid. These results constitute a baseline for the exploitation of these oils as dietary supplements against bacterial infections.

\section{Abbreviations}

ANOVA: Analysis of variance; ATCC: American type culture collection; INT:

$P$ - iodotetrazolium chloride; MIC: Minimum Inhibitory Concentrations

\section{Acknowledgements}

The authors are grateful to Dr. Oben Mbeng Lawrence for English revision.

\section{Funding}

Not applicable.

\section{Availability of data and materials \\ The dataset supporting the conclusions of this article is included within the article.}

\section{Authors' contributions}

RSM conceived the work, participated in the field work and initiated the manuscript; HMC participated in the field work and supervised the work, FNN, FNT and JDD participated in the field work; FT participated in field work and supervised the manuscript; JRK helped in data analysis and supervised the work. It should be noted that all the authors read and approved the final manuscript.

Authors' information

Not applicable.

Ethics approval and consent to participate Not applicable. 


\section{Consent for publication}

Not applicable.

\section{Competing interests}

The authors declare that they have no competing interests.

\section{Publisher's Note}

Springer Nature remains neutral with regard to jurisdictional claims in published maps and institutional affiliations.

\section{Author details}

'Laboratory of Fisheries Resources, Institute of Fisheries and Aquatic Sciences, University of Douala, Po Box 7236, Douala, Cameroon. ${ }^{2}$ Laboratory of Biochemistry of Medicinal Plants, Food Sciences and Nutrition, University of Dschang, Po Box 67, Dschang, Cameroon. ${ }^{3}$ Laboratory of Microbiology and Antimicrobial Substances, University of Dschang, Faculty of Science, Po box 67, Dschang, Cameroon

\section{Received: 29 August 2017 Accepted: 28 February 2018}

\section{Published online: 12 March 2018}

\section{References}

1. WHO. World malaria report 2011. Genève, Suisse: WHO library cataloguingin-publication data OMS; 2011. p. 278

2. Farber J. The presence of Listeria spp in raw milk. Can Journal Microbial. 1998;34:95-100

3. Mouokeu RS, Ngono Ngane RS, Njateng GSS, Kamtchueng MO, Kuiate JR. Antifungal and antioxidant activity of Crassocephalum bauchiense (hutch.) Milne-Redh ethyl acetate extract and fractions (Asteraceae). BMC Research Notes. 2014:7:244

4. Jenkins DJ, Josse AR, Beyene J, Dorian P, Burr ML, LaBelle R, Kendall CW, Cunnane SC. Fish-oil supplementation in patients with implantable cardioverter defibrillators: a meta-analysis. CMAJ. 2008;178:157-64.

5. Chitra S, Radhakrishnan. Antibactérial activities of polyunsaturated fatty acid extracts from Sardinella longiceps and Sardinella fimbriata. Idian. J Mar Sci. 2011:40(5):710-6.

6. Abgrall B, Marmonier A, Pinon G, Vargues R. Poissons et autres produits de la mer in Microbiologie Alimentaire, Aspects Microbiologique de la Sécurité et de la Qualité Alimentaire. Vol 1. Ed Tec et doc, Lavoisier, paris. 2014. P 251-264.

7. Mil-Homens D, Bernardes N, Arsenio MF. The antibacterial properties of docosahexaenoic omega-3 fatty acid against the cystic fibrosis multiresistant pathogen Burkholderia cenocepacia. FEMS Microbiol Lett. 2012;328:61-9.

8. Tenyang N. Poisson gras consommés au Cameroun : influence des traitements culinaires et de la conservation sur la qualité des lipides et des protéines. Ph,D thesis. Cameroon: University of Dschang; 2012. p. p121-2.

9. Abowei JFN, Tawari CC, Hart Al, Garicks DU. Finfish species composition, abundance and distribution in the lower Sombreiro River, Niger Delta, Nigeria. Int J Trop Agric Food Sys. 2008;2(1):46-53.

10. Merron GS, Holden KA, Bruton MN. The reproductive biology and early development of the African pike, Hepsetus odoe, in the Okavango Delta, Botswana. Environ Biol Fish. 1990;28:215-35.

11. Hopkins C, Teugels G, Melanie L. Stiassny. Poissons d'eaux douces et eaux saumâtres de basse Guinée, Ouest de l'Afrique Centrale. Vol 1. Paris. France: Institut de Recherche pour le Développement; 2007. p. 805.

12. Womeni HM, Kamga R, Tchiegang C, Kapseu C. Extraction du beurre de karité: influence du séchage des amandes et de la technique d'extraction. Riv Ital Sostanze Gr. 2002;79:33-7.

13. IDF (International dairy federation). Bacteriology chapter six. Microbiology and immunology on-line. In: Antibiotics - protein synthesis, nucleic acid synthesis and metabolism; 1991. p. 11.

14. AOCS (American Oil Chemists' Society). Official Methods and Recommended Practices of the AOCS, (5th Edn). Champaign, IL (USA), Recommended practice (ca 5c-87).1987.

15. AFNOR. (Association Française de Normalisation). Recueil des Normes Françaises. Corps Gras, Graines Oléagineuses, Produits Dérivés. 2nd ed. Paris: AFNOR; 1981. p. 438

16. Womeni HM, Tonfack DF, Anjaneyulu B, Lakshmi KMS, Narayana PRB, Linder M. Oxidative stabilization of RBD palm olein under forced storage conditions by old Cameroonian green tea leaves methanolic extract. NFS Journal. 2016:3:33-40.
17. CLSI. Methods for dilution antimicrobial susceptibility tests for bacteria that grow aerobically, approved standard. $10^{\text {th }}$ edition. 2015; 35(2):1-15.

18. Salie F, Eagles PFK, Leng HMJ. Preliminary antimicrobial screening of four south African Asteraceae species. J Ethnopharmacol. 1996:52:27-33.

19. Linder M, Fanni J, Parmentier M. Extraction, fractionnement et concentration des huiles marines. Ocl-Ol Corps Gras L. 2004;11(2):123-30.

20. Codex STAN. Programme mixte FAO/OMS sur les normes alimentaires, rapport de la vingt troisième session du comité du codex sur les graisses et les huiles. Malaisie: Langkawi; 2013. p. 270.

21. Tynek M, Hazuka Z, Pawlowicz R, Dudek M. Changes in the frying medium during deep frying of food rich in proteins and carbohydrates. J Food Lipids. 2001;8:251-61.

22. Sultana B, Faroog A, Muhammad R, Shahzad A. Antioxydant potential of extracts from different agrowastes: stabilization of corn oil. Grasas Aceites. 2008:59:205-17.

23. Eymard S. Mise en évidence et suivi de l'oxydation des lipides au cours de la conservation et de la transformation du chinchard (Trachurus trachurus). Thèse de Doctorat. Université de Nantes. Ecole polytechnique de I'Université de Nantes. France 2003. p 25-45.

24. Saify ZS, Akhtar S, Hassan S, Arif M, Ahmed F, Siddiqui SA. Study on fatty acid composition of fish oil from two marine fish, Eusphyra blochii and Carcharhinus bleekeri. Pak J Pharm Sci. 2000:13(2):5-12.

25. Huang BC, Brian G, Ebersole LJ. Antimicrobial activity of $n-6, n-7$ and $n-9$ fatty acids and their esters for oral microorganisms. Arch Oral Biol. 2010; 55(8):555-60.

26. Silva L. Antimicrobial peptides from animals: focus on drug discovery. Lett Drug Des Discov. 2011;1(3):230-6.

27. Orhan I, Ozcelik B, Senen B. Evaluation of antibacterial, antifungal, antiviral, and antioxidant potentials of some edible oils and their fatty acid profiles. Tur. J Biol. 2011;35:251-8.

28. Sugeng H S, Saraswati, Sri H ayu F I. Fatty Acid Composition of Some Potential Fish Oil from Production Centers in Indonesia. Orient J Chem. 2014:30(3):975-80

29. WHO. Model prescribing information-drugs used in bacterial infections. Genève: OMS; 2001. p. 179.

30. Cardoso O, Alves F, Leitao R. Antimicrobial susceptibility among Pseudomonas aeruginosa. Int J Infect Dis. 2008:9:12-111.

\section{Submit your next manuscript to BioMed Central} and we will help you at every step:

- We accept pre-submission inquiries

- Our selector tool helps you to find the most relevant journal

- We provide round the clock customer support

- Convenient online submission

- Thorough peer review

- Inclusion in PubMed and all major indexing services

- Maximum visibility for your research

Submit your manuscript at www.biomedcentral.com/submit
Biomed Central 